\title{
Die huisskool - 'n vorm van alternatiewe onderwys
}

\author{
G.J.J. Louw \\ Departement Fundamentele Pedagogiek \\ UNISA \\ PRETORIA
}

\begin{abstract}
The appearance of the contemporary home school in various Westem countries, including the RSA, specifically draws the attention to possible altematives for formal, institutionalised schooling. In addition to a brief explanation of the concept home school, this article also attempts 10 give an indication of the extent of the home school movement. It appears that the parents' need for adequate acknowledgement of their educative responsibility lies at the root of the founding of home schools. Against this background the article focuses on two particular reasons, the position with regard to Christian-religious convictions in public schools and the unsatisfactory academic standards of these schools. The conclusion arrived at is that home schools fulfil a specific need and should, therefore, be legalised and supported, subject to cenain conditions.
\end{abstract}

\section{INLEIDING}

Die totstandkoming van huisskole gedurende die afgelope dekade of wat kan stellig beskou word as die nuutste ontwikkeling in die Westerse wêreld ten opsigte van die hedendaagse opvatting van 'n skool. Met dié verwikkeling kom die vraag na alternatiewe vir formele geïnstitusionaliseerde onderwys opnuut skerp onder die aandag. Ondanks alle aanduidings dat hierdie verskynsel formele onderwysstelsels nie ongedeerd sal laat nie en dit selfs ingrypend kan verander, wil dit voorkom of huisskole wêreldwyd relatief min aandag in opvoedkunde-literatuur ontvang het. Dit wil trouens voorkom of die algemene publiek veel meer in dié onderwerp geïnteresseerd is as opvoedkundiges en ander navorsers (Wright, 1988:96). So onlangs as 1988 meld Van Galen (1988(a):89) nog: "... home education is only beginning to receive attention in the professional literature". Saam met die toename in die aantal huisskole is daar egter ook aanduidings dat navorsers stadigaan meer belangstelling in die verskynsel begin toon (Mayberry, 1989:172).

Hier te lande is daar sover vasgestel kon word feitlik niks oor huisskole gepubliseer nie, alhoewel die Vereniging vir Gereformeerde Tuisskole reeds in Oktober 1989 gevestig is. Dit het daartoe gelei dat waarskynlik die eerste moderne huisskool in die RSA, te wete die Paul Kruger Gereformeerde Volkskool, gedurende 1990 in Verwoerdburg tot stand gekom het. In 1991 is nog 'n vereniging, die Vereniging vir 
Gesinsonderwys, in Pretoria gestig (De Villiers, 1992). Afgesien daarvan is daar waarskynlik ook ander huisskole elders in Suid-Afrika wat, hoofsaaklik uit vrees vir moontlike vervolging, in die geheim funksioneer. Die implementering van die nuwe onderwysmodelle in die RSA en die klem wat daarin op groter ouerinspraak gelê word, maak die huisskool ook 'n relevante alternatief binne die Suid-Afrikaanse opset, veral as die tyd waarin ons leef, met veranderinge op feitlik elke terrein van die lewe, in gedagte gehou word.

In die lig van die voorafgaande is dit derhalwe noodsaaklik dat deeglik kennis geneem sal word van die hedendaagse huisskool, te meer so omdat wanvoorstellings en wanbegrip oor huisskole, dikwels juis as gevolg van gebrekkige navorsingsliteratuur, vry algemeen voorkom (Wright, 1988:96). Binne die bestek van hierdie geskrif sal egter hoogstens inleidende opmerkings oor enkele aspekte van die huisskool gemaak kan word; gevolglik sal slegs gelet word op die ontstaan en omvang van huisskole en enkele moontlike oorsake vir die ontstaan van huisskole. Alvorens die sake waarna pas verwys is, aan die orde gestel word, is 'n kort verduideliking van die begrip huisskool nodig.

\section{DIE BEGRIP HUISSKOOL}

Met die begrip huisskool word gewoonlik verwys na 'n opset waar minstens een van die ouers in 'n gesin volle verantwoordelikheid aanvaar vir die formele onderrig van hul kind(ers). Die onderrig word meestal tuis deur die moeder behartig (Wartes, 1988:45; Lowden, 1990:5) sonder dat enige vergoeding daarvoor van die staat ontvang word. Kinders wat in huisskole opgevoed word, woon dus glad nie 'n openbare of 'n privaatskool by nie.

'n Huisskool word egter nie noodwendig beperk tot die lede van 'n enkele gesin nie. As die kinders van 'n paar gesinne onderrig word deur een van die ouers of deur' $n$ ouer wat nie aan enige van die gesinne verbonde is nie, kan steeds van 'n huisskool gepraat word (Meighan, 1984:167; Divoky, 1983:397). Onderwysers of ander kundiges uit die gemeenskap kan byvoorbeeld benut word om bepaalde aspekte te onderrig waarvoor die ouer nie self kans sien nie (Wartes, 1988:45)

Dit word skynbaar ook nie as vereiste gestel dat 'n ouer of 'n ander volwassene self die onderrig moet behartig nie. Onderrig in huisskole kan ook deur 'n ouer broer/suster, studente of deur middel van afstandsonderrig verskaf word (Meighan, 1984:167; Van Galen, 1988(b):58), solank dit onder toesig (beheer) van 'n ouer of selfs 'n ander volwasse familielid soos 'n grootouer geskied. 
Uit die voorafgaande blyk reeds dat alle huisskole nie op dieselfde wyse bedryf word nie, maar dat ' $n$ verskeidenheid benaderings gevolg word. Ray (1988:17) vestig die aandag pertinent op hoe moeilik dit is om die "... plurality and multiple dimensions" van huisskole en huisskoolouers vas te vang. Daar sal nie hier verder op die aangeleentheid ingegaan word nie, maar volstaan word met die opmerking dat sommige huisskole uiters streng gestruktureer is, terwyl ander weer redelik ongestruktureer is.

Met inagneming van wat tot dusver oor huisskole aangevoer is, wil dit voorkom of daar aan die volgende vereistes voldoen moet word ten einde as 'n huisskool te kwalifiseer:

- Kinders moet tuis deur 'n volwassene (verkieslik 'n ouer) onderrig ontvang of geleentheid daartoe gebied word onder toesig van 'n ouer of 'n volwasse familielid.

* Om te voorkom dat die huisskool in 'n gewone skool ontwikkel en gekonfronteer word met daardie probleme waaraan huisskoolgesinne wil ontkom (Divoky, 1983:397), moet 'n huisskool klein wees, en vir nie meer as hoogstens tien kinders verantwoordelikheid aanvaar nie.

- Die huisskool moet nie net self oor die hoogste mate van outonomie beskik nie, maar moet ook 'n besonder hoë premie plaas op die selfstandigheid en outonomie van die huisgesin. Van Galen (1988(b):96) laat haar in dié verband soos volg uit: "From the beginning, home education was a private, personal, family enterprise." As sodanig is die huisskool 'n openbare verklaring van ouers se geloof in die

- huisgesin as instelling (Van Galen, 1988(a):104) en 'n poging om die ouerlike roeping te vervul. Aangesien die pas gemaakte stelling verband hou met die ontstaan van huisskole sal in die volgende paragraaf daarop ingegaan word. In samehang daarmee sal ook 'n breë oorsig gebied word oor die omvang wat die huisskoolbeweging reeds aangeneem het.

\section{ONISTAAN EN OMVANG VAN DIE HUISSKOOLBEWEGING}

Wat tot dusver oor huisskole aangevoer is, is nie bedoel om die indruk te wek dat huisskole 'n totaal nuwe verskynsel op onderwysgebied is nie. In der waarheid gaan dit om 'n herlewing van 'n baie ou en redelik algemene praktyk. In talle Westerse lande is kinders vry algemeen feitlik uitsluitlik tuis onderrig (Knowles, 1989:395; Mayberry, 1989:171; Cizek, 1990:110). Tuisonderrig was dikwels ook hier te lande die enigste onderrig wat die vroeë pioniers en Voortrekkers se kinders ontvang het. Hierdie soort "family-controlled learning" (Mayberry, 1989:17) kan dus tereg as die mees tradisionele skoolvorm beskou word. 
Die groot verskil tussen die moderne huisskool en die huisskool van vroeër is dat ouers nou om 'n verskeidenheid redes verkies dat hul kinders nie staat- of privaatskole moet bywoon nie, terwyl ouers vroeër feitlik geen ander keuse gehad het as om hulle kinders tuis te (laat) onderrig nie.

\subsection{Ontevredenheid met die openbare onderwysstelsel}

Dit wil voorkom of die ontstaan van die moderne huisskoolbeweging en huisskole veral spruit uit die ontevredenheid met die openbare skoolbestel wat teen die einde van die sestigerjare van hierdie eeu in verskillende wêrelddele opgevlam het. In dié verband moet veral herinner word aan die invloed wat deur mense soos I. Illich, A.S. Neill, J. Holt, P. Freire en H. Marcuse uitgeoefen is (Knowles, 1989:396). Hulle het hulle onder andere daarvoor beywer dat die samelewing 'ontskool' moet word en dat voorsiening vir sogenaamde 'alternatiewe onderwys' gemaak moet word. In ooreenstemming met die denkbeelde van Illich, Neill en hul geesgenote beklemtoon huisskoolouers dit ook dat onderwys nie net in staat- of privaatskole plaasvind nie en dat dié inrigtings geen alleenreg op onderwys het nie (Divoky, 1983:395; Meighan, 1984:166167). Moontlik juis op grond van hierdie ooreenkoms tussen huisskoolouers en die sogenaamde onderwyshervormers soos Illich en andere word gesinne wat huisskole bedryf, soms beskou as "... a group of radical de-schoolers, and anti-establishment activists vaguely labelled as "left wing"' (Meighan, 1984:166).

Dat huisskole aanvanklik hoofsaaklik geassosieer kon word met 'n linkse/liberale/radikale stroming is moontlik. Tans is huisskole egter nie beperk tot 'n bepaalde groep nie, aangesien ouers uit alle lae van die bevolking en ouers met die mees uiteenlopende politieke oortuigings en lewensopvattings by huisskole betrokke is. As sodanig verteenwoordig ouers wat by huisskole betrokke is 'n breë spektrum van huisgesinne in die samelewing. Dit word ondubbelsinnig bevestig deur die volgende uitlating:

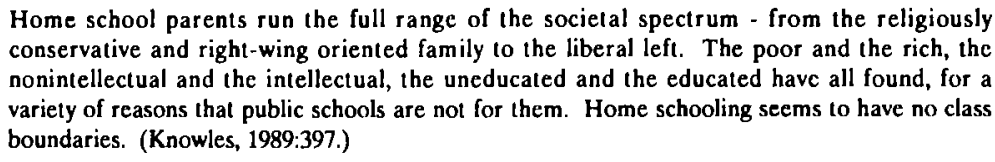

Home school parents run the full range of the socielal spectrum - from the religiously conservative and right-wing oriented family to the liberal left. The poor and the rich, the nonintellectual and the intellectual, the uneducated and the educated have all found, for a variety of reasons that public schools are not for them. Home schooling seems to have no class boundaries. (Knowles, 1989:397.)

In die lig daarvan is dit dus geen maklike taak om huisskoolouers te tipeer nie. Oor die algemeen dui navorsingsbevindinge egter daarop dat huisskoolouers in vergelyking met ander ouers beter akademiese kwalifikasies het (Knowles, 1988(b):72; Pitman, 1987:284). Of huisskoolouers oor die algemeen ook finansieel beter daaraan toe is, is nie 'n uitgemaakte saak nie. Mayberry (1988:33-34) bevestig dat huisskoolouers wel beter daaraan toe is, terwyl sowel Knowles (1988(b):71) as Meighan (1984:166) beweer 
dat die meeste huisskoolgesinne in die middel- en laerinkomstegroepe val en selfs finansieel swaar kry.

\subsection{Die groei van die huisskoolbeweging}

Hoewel die moderne huisskool sy ontstaan in die VSA en Brittanje gehad het, is huisskole nie net tot dié lande beperk nie soos reeds terloops opgemerk is. Ander Westerse lande waar huisskole voorkom en/of reeds gevestig is, is onder andere WesDuitsland, Frankryk, Kanada, Ierland, Australië, Nieu-Zeeland en soos vroeër vermeld die RSA. 'n Duidelike toename in huisskoolonderrig en belangstelling in huisskole word trouens nie net in die genoemde lande nie maar ook in die res van die wêreld waargeneem (Pitman, 1987:280).

In die VSA was daar veral die afgelope dekade 'n verhoogde belangstelling in huisskole en 'n aansienlike toename in die aantal huisskole. Verskeie navorsers wys daarop dat die verskynsel in so ' $n$ mate besig is om deur Amerika te versprei dat dit een van die segmente van die Amerikaanse onderwysstelsel is wat die vinnigste groei (Rakestraw \& Rakestraw, 1990:67; Frost \& Morris, 1988:223; Common \& MacMullen, 1986:4).

Die groei van die huisskoolbeweging moet in samehang met die wettiging van tuisonderrig gesien word. In die literatuur is daar nie eenstemmigheid oor die aantal state waarin huisskole toegelaat word nie. Volgens Rakestraw en Rakestraw (1990:72) het 28 state sedert 1980 huisskoolstatute of -regulasies aanvaar, terwyl kinders wat huisskole bywoon in 31 state eksplisiet vrygestel word van verpligte skoolbywoning. Cizek (1990:116) wys daarop dat huisskole spesifiek kragtens wet in 30 state toegelaat word. Daarteenoor word daarop gewys dat daar reeds in 1986 net 12 state was wat huisskole nie toegelaat het nie (Common \& MacMullen, 1986:5). Reeds in 1988 was die posisie volgens Van Galen (1988(b):65) dat huisskole in een of ander vorm in elke staat in die VSA toegelaat word. Dit word ook deur Rakestraw en Rakestraw (1990:71) bevestig wat uitdruklik verklaar: "... every state has been allowing home schooling in some form or another even while imposing some regulations to protect the right of the state to an educated citizenry".

Oor die presiese aantal kinders in huisskole is daar nie duidelikheid nie. Dit is onder andere daaraan toe te skryf dat baie ouers, uit vrees vir moontlike vervolging, huisskole in die geheim bedryf (Knowles, 1989:401; Divoky, 1983:396; Cizek, 1990:112; Frost \& Morris, 1988:225). Navorsers maak ook melding van hofsake teen ouers wat hul kinders tuis onderrig (Pitman, 1987:285, Divoky, 1983:397-398; Cizek, 1990:111-112). Dié toedrag van sake noop Van Galen (1988(a):96) om te verklaar dat ouers wat 
besluit om 'n huisskool te begin heel eerste moet leer hoe om regsvervolging te voorkom. Vrees vir moontlike vervolging lei daartoe dat ouers hul kinders vir die skyn by privaatskole inskryf wat gewillig is om as front vir huisskole te dien (Divoky, 1983:398). Hierdie praktyk maak dit nog moeiliker om die presiese aantal kinders wat by huisskole betrokke is, te bepaal. Na raming word egter reeds soveel as een miljoen kinders in die VSA tuis onderrig (Frost \& Morris, 1988:223; Mayberry, 1989:171; Knowles, 1989:393; Cizek, 1990:110).

Die mate waarin die huisskoolbeweging reeds inslag in die VSA gevind het, blyk ook uit die feit dat daar huisskoolnuusbriewe en -tydskrifte is wat gereeld en op 'n nasionale basis versprei word. Hierbenewens het ook 'n netwerk ondersteunende dienste ontwikkel waardeur huisskole (beter) vir hul taak toegerus word (Van Galen, 1988(b):54); Divoky, 1983:396). In die Verenigde Koninkryk verskaf organisasies soos Education Otherwise en die Childrens' Home-based Education Association advies en ondersteuning aan gesinne wat huisskole bedryf of dit oorweeg (Meighan, 1984:165).

Die vordering van die huisskoolbeweging is des te merkwaardiger as in gedagte gehou word dat die besluit om kinders tuis te onderrig, veel meer van ouers verg as om hul kinders na gewone skole te stuur. Van die probleme waarmee sulke ouers gekonfronteer word, blyk uit die volgende opmerking van Van Galen (1988(b):65): "When they dissent from school, they do so at considerable legal, personal and political risk." Cox (1990:8) skryf dit daaraan toe dat die samelewing nie so gestruktureer is om huisskole 'n maklike keuse te maak nie. 'n Verdere faktor wat die stigting van huisskole beperk, is die strawwe ekonomiese toestande wat bykans wêreldwyd ondervind word, en waardeur albei ouers genoop word om 'n voltydse betrekking te beklee (vgl. Divoky, 1983:397)

Dit is betekenisvol dat die groei van die huisskoolbeweging gepaard gaan met 'n toename in die aantal privaatskole en in die leerlingtal van dié skole. Teen 1992 sal na verwagting reeds meer as $11 \%$ van die totale $\mathrm{K}-12$ leerlingbevolking in die VSA by privaatskole geregistreer wees (Ornstein, 1990:210).

Met inagneming van die voorafgaande wil dit voorkom of minstens die openbare skool in verskeie Westerse lande nie meer aan die verwagtinge van 'n aansienlike en toenemende aantal ouers voldoen nie. In die lig daarvan is dit derhalwe noodsaaklik dat die vraag na spesifieke oorsake vir die ontstaan van huisskole aan die orde gestel word. Daar word immers nie verniet gewaarsku nie dat opvoedkundiges en onderwysadministrateurs wat doelbewus huisskole en diegene wat daarby betrokke is ignoreer, 'n flagrante oordeelsfout begaan (Frost \& Morris, 1988:223). 


\section{SPESIFIEKE REDES VIR DIE ONTSTAAN VAN HUISSKOLE}

Dit is inderdaad so dat daar veelvuldige en komplekse redes is waarom ouers huisskole bo gewone staat- en privaatskole verkies. Dat dit egter geen maklike taak is om die redes te verstaan nie, word bevestig deur die volgende uitspraak:

The multiple conclusions reached by researchers underscore the difficulty of understanding the complex reasons why parents elect to educate their children at home. (Knowles, 1988(b):72- 73.)

In die verband moet rekening gehou word daarmee dat die besondere omstandighede wat lei tot ouers se besluit om kinders tuis te onderrig, wissel van gesin tot gesin (Van Galen, 1988(a):91). Soms berus die besluit op 'n enkele deurslaggewende rede en in ander gevalle op 'n paar redes. Dikwels speel huisskoolouers se eie ervarings met skole ook 'n beslissende rol in hul siening van skole en in hul regverdiging van huisskole. Knowles (1988(b):73-75) is selfs van mening dat ouers se vroeëre ondervinding met skole meestal onderliggend is vir watter rede ook al aangevoer word vir hul besluit ten gunste van huisskole.

Al hierdie redes kan egter herlei word tot ontevredenheid, teleurstelling en ontnugtering met veral openbare skole (vgl. Pitman, 1987:281; Divoky, 1983:397; Frost \& Morris, 1988:223; Knowles, 1989:396). As sodanig reflekteer huisskole nie net 'n weerstand teen staatskole nie, maar ook 'n ontnugtering met en 'n afkeer van die heersende tydsgees en maatskaplike bestel (Mayberry, 1988:40). Die weerstand sentreer om die oortuiging dat openbare skole nie in staat of daarin geïnteresseerd is om aan kinders die soort opvoeding te verskaf wat ouers verlang nie. Daardeur demonstreer openbare skole dat hulle nie die gemeenskap en die kinders van daardie gemeenskap se beste belange op die hart dra nie (Cizek, 1990:111).

Met verwysing na die Verenigde Koninkryk word uitdruklik verklaar: "... both state and private schools are, in the long run, more likely to do damage to a child's education than anything positive" (Meighan, 1990:3). Waarskynlik hou veral veelrassige en multikulturele skole van die ernstigste bedreiginge in vir outentieke opvoeding en voortreflike akademiese onderwys. Daarom verwag ouers van die skool om toe te sien dat die kultuur, taal en lewensopvatting van die gemeenskap wat dit bedien, behoue bly en dat dié sake nie opgeoffer sal word ter wille van 'n sogenaamde nie-rassistiese benadering in die onderwys nie. Van Galen (1988(b):52) laat geen twyfel daaroor dat die moderne multikulturele en veelrassige openbare skole nie aan alle ouers en kinders se verwagtinge kan voldoen nie as sy haar soos volg uitlaat: "The long-held assumption that schools serve children from broad and diverse backgrounds, equally well has been all but discredited." In die lig van die voorafgaande het talle ouers nie net ernstige bedenkinge oor die aanvaarbaarheid en noodsaaklikheid van 
Die huisskool - 'n vorm van altematiewe onderwys

onderwys in openbare skole vir behoorlike opvoeding en sosialisering nie, maar verwerp steeds meer Amerikaanse ouers geïnstitusionaliseerde vorms van onderwys.

Die mate waarin Amerikaanse ouers reeds vertroue in die openbare skool verloor het (Mayberry, 1989:177) blyk onder andere uit onlangse meningspeilings. Daarin is bevind dat meer as $50 \%$ ouers met kinders in openbare skole dit oorweeg om hul kinders in privaatskole te plaas. Indien die staat maatreëls sou instel om dit finansieel meer bekostigbaar te maak, sou sowat $25 \%$ ouers beslis hul kinders in privaatskole plaas (Ornstein, 1990:212).

Die vertrouensbreuk en die gevolglike verwerping van die openbare skool is grootliks daaraan toe te skryf dat die ouer se aandeel en inspraak in die formele onderwys die afgelope drie dekades geleidelik maar substansieel geminimaliseer is. Terselfdertyd is die opvoeding van die kind al meer deur die skool oorgeneem (Wright, 1988:112). Uitsprake van sogenaamde kundiges wat ouers tydig en ontydig daaraan herinner dat hulle nie (meer) in die moderne, vertegnologiseerde samelewing in staat is om hul kinders se opvoeding te behartig nie, maar die taak aan eksperte moet oorlaat, het veel bygedra tot dié toedrag van sake. Talle probleme wat in die openbare onderwysstelsel ondervind word, spruit juis voort uit die wanopvatting dat opvoeding die skool (staat) se verantwoordelikheid is (Rupik, 1990:6). Dat ouers egter nie langer gediend is met die minderwaardige rol wat aan hulle toegeken word nie, blyk uit hulle aandrang op meer seggenskap en verantwoordelikheid in die onderwys van hul kinders. Dít kan inderdaad beskou word as die primêre rede vir die stigting van huisskole. Trouens, by huisskoolouers is daar ' $n$ gemeenskaplike strewe "... to either reclaim or not to relinquish control of their childrens' education to public institutions" (Mayberry, 1989:177). Daarom beywer hierdie ouers hulle vir 'n meer tradisionele soort onderwys wat deur die ouers binne gesinsverband beheer word. Ter wille daarvan dring huisskoolouers sigbaarder en luider as ander ouers aan op erkenning van die gesin se integriteit (Van Galen, 1988(a):104).

Die besluit om hul kinders tuis te onderrig, word gewoonlik voorafgegaan deur' $n$ redelike lang tydperk waarin ouers toenemend ontevrede en ontnugter raak met openbare skole. Dis meestal eers na deeglike oorweging van alle ander alternatiewe en nadat hulle oortuig daarvan is dat daar vir hulle geen ander uitweg is nie, dat die ouers hulle tot huisskole wend (Van Galen, 1988(a):93).

Dit is egter nie net ouers wat ontevrede is met die onderwysstelsel nie, maar ook onderwysers (Skiera, 1990:7). In die verband kan melding gemaak word van die feit dat in bykans elke Westerse land derduisende onderwysers jaarliks die onderwysprofessie verlaat, nie omdat hulle die aftree-ouderdom bereik het nie, maar om 'n heenkome in 'n ander beroep te vind. By meer as een navorser is daar geen twyfel nie 
dat die uiltog van onderwysers in Europa wel verband hou met die skool as instelling in sy huidige vorm en die onaanvaarbare stand van die onderwys (Skiera, 1990:7). Daaroor laat Lowden (1990:5) hom soos volg uit:

If 20,000 tcachers can leave their profession in a year, it must surely reflect a considerable degree of frustration and concern within the system.

Met inagneming daarvan is dit betekenisvol dat so 'n groot persentasie huisskoolouers gekwalifiseerde onderwysers is (Webb, 1990:10). In die geval van Education Otherwise is meer as $25 \%$ van die lede van die organisasie opgeleide onderwysers (Lowden, 1990:4). Hierdie toedrag van sake laat die vraag ontstaan of dit nie juis onderwysers se eerstehandse kennis is van wat in skole plaasvind wat hulle noop om hul kinders tuis te onderrig nie.

Teen die agtergrond van die voorafgaande word vervolgens enkele spesifieke redes vir die ontstaan van huisskole aan die orde gestel. Binne die bestek van hierdie artikel sal veral op die VSA gekonsentreer word en sal hoogstens kursories op godsdienstige oorwegings en kommer oor akademiese standaarde ingegaan word. Daarmee word nie noodwendig te kenne gegee dat dié sake tans in die blanke onderwys in die RSA eweveel rede tot kommer bied nie.

\subsection{Christelik-godsdienstige oorwegings}

Verreweg die meeste ouers wat hulle tot huisskole wend, doen dit om godsdienstige redes (Common \& MacMullen, 1986:5; Divoky, 1983:396). Navorsers beraam dat tussen $65 \%$ en $90 \%$ van alle huisskoolouers juis om dié rede huisskole bedryf (Mayberry, 1988:37; Cizek, 1990:110). Meer spesifiek gaan dit egter daarom dat Christelikgodsdienstige oortuigings veral in openbare skole of glad nie of nie genoegsaam neerslag vind nie, maar dat hoogstens volstaan word met 'n soort sekulêre humanisme (Zeichner, 1991:370-371; Divoky, 1983:396; Knowles, 1988(b):74). Tekenend van hierdie toedrag van sake waarteen 'n toenemende aantal ouers openlik in verset kom, is uitsprake waarin dit duidelik gestel word dat diegene met spesifieke godsdienstige oortuigings nie kan verwag dat die openbare skool dié oortuigings moet bevorder en daardeur leerlinge met ander oortuigings in die verleentheid stel nie (Campbell, 1976:225). Dat dié soort uitsprake egter daarop gemik is om die Christendom te benadeel, blyk onder andere uit die volgende aanhaling:

They have laken Christ out of Christmas and now it's winter break; they have laken the resurrection out of Easter and now it's spring break; but they are determined to leave witches and satan in Halloween. (Mayberry, 1989:175.) 
Vir verreweg die oorgrote meerderheid Christen-ouers is die aanslag op die Christelike godsdiens met die daarmee gepaardgaande sedelike verval wat in die samelewing plaasgevind het, derhalwe 'n bron van ernstige kommer (Mayberry, 1988:40). Jonathan (1989:321) wys tereg op die ernstige implikasies wat dié toedrag van sake vir die opvoeding inhou wanneer hy daaraan herinner dat opvoeding 'n weerspieëling is van die waardes van 'n bepaalde gemeenskap, maar terselfdertyd ook die instandhouding daarvan in die toekoms wil verseker.

In ooreenstemming met die aanslag op die Christendom word kinders in openbare skole in die VSA blootgestel aan anti-Christelike lesmateriaal en ontvang hulle antiChristelike onderwys (Cizek, 1990:110). Dit blyk daaruit dat in dié skole nie uit die Bybel gelees en gebid (mag) word nie. Ook die verkondiging van die evolusieleer in openbare skole druis in teen talle huisskoolouers se Christelike geloofsoortuigings (Mayberry, 1988:37). By Ornstein (1990:211) is daar geen twyfel nie dat die toename in Christelike privaatskole in Amerika uitsluitlik daaraan toe te skryf is dat sienderoë toegelaat is dat God en die Christelike godsdiens deur ateiste en die howe uit die openbare skool verdryf is. Aangesien die openbare skool in die VSA in stryd met die Christelike opvoeding van die ouerhuis optree, veroorsaak dit nie net spanning tussen ouer en kind nie, maar word die openbare skool in 'n toenemende mate as 'n onveilige en immorele milieu beskou.

Hoewel die afwesigheid van rigtinggewende Christelike beginsels geen vak ongedeerd laat nie is huisskoolouers veral ook bekommerd oor die verreikende invloed daarvan op die wyse waarop seksonderrig in openbare skole in die VSA hanteer word. In dié verband moet steeds in gedagte gehou word dat seksualiteit vir die Christen die mens in sy diepste wese van menswees raak. Huntemann (1964:10) verwoord dit soos volg: "Er bestaat geen seksualiteit die niet met de ziel van die mens ... te maken heeft." In 'n samelewing waarin alles geregverdig word in naam van respek vir diversiteit skyn dit of die Christen se verhewe siening van seksualiteit grootliks geïgnoreer word en seksualiteit gereduseer word tot seksuele lus wat onmiddellik bevredig moet word. Daardeur word seksuele losbandigheid en seksuele permissiwiteit met 'n daarmee gepaardgaande negatiewe gesindheid teenoor die huwelik as Christelike instelling bevorder. Kragtens hierdie sogenaamde moderne opvatting van seksualiteit is alle seksuele gedraginge in die moderne plurale samelewing aanvaarbaar en toelaatbaar (vgl. Louw, 1991:450-451). Meer nog: ondanks die feit dat dit indruis teen die Christelike oortuigings van ouers, word kinders in openbare skole in die VSA uitvoerig met afwykende seksuele gedrag bekend gestel (Steinbacher, 1971; Divoky, 1983:396).

Veral na die uitbreek van Vigs word 'n omvattende bekendstelling met selfs die mees walglike seksuele gedrag, daarmee geregverdig dat dit noodsaaklik is vir die bekamping van Vigs (Louw, 1991:453). Daaroor laat Macklin (1988:145) geen twyfel nie: "... 
to educate effectively requires a direct and explicit discussion of the very sexual practices which many may find repulsive or at least embarrassing". Dit word dan ook benadruk dat die bedreiging wat Vigs inhou, spesifiek benut moet word om die behoefte aan meer kennis van homoseksualisme te beklemtoon. Onderrig oor homoseksualisme word egter ook as noodsaaklik voorgehou om die aanvaarding van alle mense in 'n multikulturele samelewing te bevorder. Trouens, in Madison, Wisconsin is een van die temas van die multikulturele kurrikulum van die Madison Metropolitan School District juis homoseksualisme (Zeichner, 1991:370).

Uit die voorafgaande blyk duidelik dat openbare skole in die VSA toenemend in 'n relativisme en 'n nihilisme verval. Immers, waar geen fundamentele waarhede en waardes erken en gerespekteer word nie, verval alle onderskeid tussen reg en verkeerd. Juis daarteen maak huisskoolouers ernstig beswaar (vgl. Divoky, 1983:396; Mayberry, 1989:174) omdat die mens en veral die kind daardeur in vertwyfeling gedompel word en 'n eksistensiële krisis ervaar. Dit word deur Pitman (1987:280) bevestig wat onomwonde verklaar dat die krisis waarin die Amerikaanse skoolstelsel hom bevind te wyte is aan 'n sinskrisis. Hierdie krisis word sigbaar gedemonstreer onder andere in die hoë uitsaksyfer en die groot aantal leerlinge wat hulle skuldig mak aan dwelmmisbruik en stokkiesdraai. Die National Center for Education stel die nasionale uitsaksyfer in die VSA op $27 \%$, terwyl dit na raming tot soveel as $40-60 \%$ styg in die groot stedelike gebiede (Loughrey \& Harris, 1990:187-188). Volgens Pitman (1987:285) wat 'n vergelyking tref tussen die aantal leerlinge jonger as 16 jaar wat uitsak en die aantal kinders in huisskole is die uitsakkers bykans vier maal meer as die huisskoliere. Ironies genoeg word egter baie selde teen die uitsakkers of hul ouers kragtens skoolpligregulasies opgetree. Daarbenewens draai sowat $20-50 \%$ leerlinge van openbare skole gereeld stokkies sonder dat bywoningsbeamptes hulle veel daaraan steur. Op grond daarvan word verklaar dat dit wil voorkom of maatreëls wat verpligte skoolbywoning reël, uitsluitlik van toepassing gemaak word op huisskole. Met verwysing na sake soos skoolplig en stokkiesdraaiery merk Pitman (1987:288) tereg op:

To focus on them to the exclusion of the content of schooling is to put up a smoke screen obscuring the essential crisis in meaning confronting American education today.

Huisskole bied egter aan ouers die geleentheid om hul kinders te beskerm teen die anti-Christelike en sogenaamde progressiewe humanistiese waardes wat veral tans in die VSA deur openbare skole verkondig word. Dit help om versteurde verhoudings tussen ouer en kind wat uit die anti-Christelike onderwys voortspruit, te verbeter (Meighan, 1984:171; Pitman, 1987:281). Bowenal stel dit ouers in staat om hul kinders doelgerig te begelei en te vervul met 'n onwrikbare geloof in die Skrif as die hoogste openbaring van God se gesag. In die lig daarvan is 'n Christelik-deurdrenkte opvoeding vir Christen-huisskoolouers 'n Godgegewe verantwoordelikheid wat nougeset nagekom moet word, omdat huisskole vir die ouers eenvoudig 'n logiese uitvloeisel is 
van die Bybel se mandaat dat ouers primêr verantwoordelik is vir die opvoeding van hul kinders (Cizek, 1990:110: Mayberry, 1988:37). As sodanig is huisskole 'n openbare verklaring van die ouer se geloof in die huisgesin as instelling en die aanvaarding van die verpligtinge wat dit meebring. Huisskoolouers is daarvan oortuig dat hulle net deur hul Christelike verantwoordelikheid stip na te kom, kan verseker dat Christelike moraliteit herstel en bewaar word (Knowles, 1988(b):74; Mayberry. 1989:174) en die kinders wat aan hul toevertrou is, gehelp kan word om die sin van die lewe te ontdek.

Hierdie ouers is egter nie net vasberade om te verseker dat hul kinders 'n Christelike opvoeding ontvang nie, maar ook dat 'n hoë akademiese standaard gehandhaaf sal word. In die volgende afdeling sal op laasgenoemde aspek gelet word.

\subsection{Die handhawing van hoè akademiese standaarde}

Sedert die middel sewentigerjare, maar veral in die tagtigerjare word feitlik wêreldwyd met toenemende kommer melding gemaak van die agteruitgang in die gehalte van die openbare onderwys (Knowles, 1988(a):8). Met betrekking tot die onderwysstandaard in die VSA, konstateer Mulkova (1989:33):

Regular national surveys of education conducted in the United States and the results of university entrance cxaminations demonstrate a steady downward trend in levels of knowledge, skills and habits in reading, writing, mathematics and science.

Hierdie agteruitgang word deur talle belanghebbendes beskou as 'n sigbare manifestasie van die mislukking van die openbare skool, en lei daartoe dat leerlinge en hul ouers al hoe minder belangstel in die skool en sy werksaamhede (Mulkova, 1989:3536). In die lig daarvan is dit nie vreend dat die skool se onvermoë om hoë akademiese standaarde te handhaaf as die tweede vernaamste rede vir die stigting van huisskole aangedui word nie (Mayberry, 1988:37; Knowles, 1988(a):8, 9; Mayberry, 1989:177).

Een van die redes wat aangevoer word waarom hoëgehalte-onderwys en hoë akademiese standaarde nie gehandhaaf kan word nie, is steeds strawwer ekonomiese toestande wat feitlik wêreldwyd ondervind word. As gevolg daarvan is talle lande verplig om op onderwysuitgawes te besnoei (vgl. Mayberry, 1988:37-38; Knowles, 1989:9). 'n Verdere rede wat daarmee verband hou, is die toename in die leerlinggetalle van sekondêre skole in die VSA (Ornstein, 1990:10; Mulkova, 1989:35). In die praktyk vind dit oor die algemeen neerslag in groter klasse (meer leerlinge per onderwyser) en minder individuele aandag (Mulkova, 1989:15). Verskeie navorsers wys daarop dat onvoldoende individuele aandag aan leerlinge juis een van die vernaamste redes is waarom ouers hulle kinders tuis (laat) onderrig (vgl. Ray, 1988:17; Knowles, 1989:399-400; Lowden, 1990:4). 
Die hoogs geïndividualiseerde een-tot-een onderrig- en leersituasie in die huisskool hou uiteraard heelwat voordele in, soos dat elke leerling teen sy eie pas kan vorder en maksimale terugvoering oor sy vordering kan ontvang. Huisskole bied ook aan leerlinge die geleentheid om met veel meer vrymoedigheid deel te neem aan die onderrigleergebeure, terwyl die hele opset in 'n huisskool 'n positiewe uitwerking het op die selfvertroue en die selfbeeld van huisskoolkinders (vgl. Charvoz, 1988:88-89, 92; Ray, 1988:21).

In aansluiting daarby huldig huisskoolouers die standpunt dat openbare skole weetgierigheid, kreatiwiteit, ondernemingsgees, individualiteit en selfstandigheid smoor en strakke eenvormigheid, verbeeldingloosheid en verveeldheid bevorder. Daaroor laat die volgende opmerking geen twyfel nie:

For many home school parents public and formal schonling represents cocrcion, repression of individuality, and conformity to the majority's whims. (Knowles, 1989:398; vgl. ook Divoky, 1983:397.)

Wanneer besin word oor die akademiese voortreflikheid van huisskole behoort ook aandag gegee te word aan die beskikbaarheid van onderrighulpmiddele. Webb (1990:11) is van mening dat hoewel huisskole nie oor al die onderrighulpmiddele van konvensionele skole beskik nie, daar weinig indien enige bewys is dat 'n huisskoolkind se vordering ernstig daardeur benadeel word. Daarteenoor word daarop gewys dat 'n tipiese Amerikaanse huishouding in die laaste dekade van die twintigste eeu in elk geval beskik oor voldoende gesofistikeerde toerusting soos persoonlike rekenaars, kleurtelevisie met teleteks, video- en klankopnemers wat onmiddellik deur 'n huisskolier benut kan word (Lowden, 1990:4). Huisskoolouers maak gevolglik daarop aanspraak dat die ouerhuis, ook vanweë die beperkte leeromgewing van die openbare skool, die beste toegerus is om 'n kind se akademiese potensiaal te ontwikkel en in spesiale akademiese behoeftes te voorsien. Knowles (1988(a):11-12) wat dieselfde mening huldig, vestig die aandag daarop dat "... the very nature of the home school environment provides opportunities to implement strategies that are beyond the realm of many classroom teachers". In die lig van die voorafgaande word nie net verklaar dat die ouerhuis die beste leeromgewing is nie, maar ook dat ' $n$ kind se eie ouers sy beste onderwysers is (Common \& MacMullen, 1986:7; Mayberry, 1989:176).

Tans het dit nodig geword om aandag te gee aan die akademiese prestasie van huisskoolkinders. In dié verband kan kennis geneem word van die bevindinge van etlike navorsers wat die akademiese prestasie van kinders in huisskole en in gewone skole in state soos New York, Arkansas, Arizona, Oregon, Tennessee, Alaska en Kalifornië met mekaar vergelyk het. Die eenparige gevolgtrekking waartoe geraak is, is dat huisskoolkinders minstens net so goed vaar soos leerlinge in gewone skole en ook geen agterstand teenoor sulke leerlinge het nie. Met verwysing na die akademiese prestasie 
Die huisskool - 'n vorm van alternatiewe onderwys

van huisskoolkinders in Washington en die pas vermelde state lewer Wartes (1988:4950) die volgende uitspraak:

I have been unable to find even one study that has produced below-average mean scores on a home schooling population. Home schools do appear to produce good results.

Oor die algemeen presteer huisskoolkinders in dieselfde toetse egter meestal beter en selfs heelwat beter as leerlinge in konvensionele skole (vgl. Boulter, 1990:21-22; Pitman, 1987:284; Divoky, 1983:395; Wright, 1988:107; Ray, 1988:20-25), terwyl dit selfs wil voorkom of huisskoolkinders nog beter presteer as leerlinge in gewone skole hoe langer hulle in huisskole onderrig word (Pitman, 1987:284). Die sukses wat huisskoolkinders behaal, word veral toegeskryf aan die gemotiveerdheid, erns en toewyding waarmee huisskoolouers hul opvoedingsverantwoordelikheid nakom (vgl. Ray, 1988:26; Knowles, 1988(a):12).

In die RSA is daar egter nog nie enige navorsing onderneem ten einde die akademiese gehalte van die onderrig in huisskole hier te lande te bepaal nie. Die enigste leerling van die Paul Kruger Gereformeerde Volkskool wat in 1990 die Nasionale Seniorsertifikaateksamen afgelê het, het volgens sy moeder (De Villiers, 1992) vyf A's en 'n C in die eksamen behaal. In dié verband behoort ook kennis geneem te word van die feit dat die leerling in twee vakke A's behaal het, terwyl hy C's vir dieselfde vakke in die st. 9 -eksamen in die openbare skool behaal het. Dié persoon wat 'n ingeskrewe tweedejaarstudent in die metallurgiese ingenieurswese aan die Universiteit van Pretoria is, het ook sy eerstejaarskursus in 1991 met onderskeiding voltooi.

Ten slotte behoort ook aandag gegee te word aan die vraag of die akademiese prestasie van huisskole nie slegs moontlik is as oormatig klem gelê word op intellektuele ontwikkeling ten koste van ander fasette van menswees nie. In dié verband is die sosialisering van huisskoolkinders van besondere belang. Anders egter, as wat soms beweer word, ondervind hierdie kinders weinig of geen sosialiseringsprobleme nie (vgl. Webb, 1990:11; Boulter, 1990:22; Charvoz, 1988:87). Common en MacMullen (1986:6) se verklaring daarvoor is dat "... a child's social-emotional development is best fostered, not by increased peer contact, but by the sense of self-worth and a stable value system". In die lig daarvan is dit nie vreemd nie dat verklaar word dat juis huisskole kinders deeglik toerus om hul plek in die samelewing vol te staan, terwyl dit kategories gestel word dat openbare skole, soos dit tans is nie in staat is "... of producing the flexible people needed to cope with the rapid changes associated with the decline of work and the increase in leisure" (Meighan, 1984:169). 


\section{SAMEVATTEND}

Dit wil voorkom of ouers se ontevredenheid met veral die openbare staatskool en die houding van onderwysowerhede teenoor huisskole die twee vernaamste faktore is wat die toekoms van huisskole sal bepaal. Daar is reeds aandag gegee aan enkele redes vir ouers se ontevredenheid met staatskole, terwyl ook terloops melding gemaak is van onderwysowerhede se houding oor huisskole. Hoewel sommige onderwysadministrateurs vyandiggesind is en huisskole met alle moontlike middele beveg (vgl. Pitman, 1987:284-285; Van Galen, 1988(b):65; Meighan, 1984:169), moet in gedagte gehou word dat ekstreme onderdrukkende maatreëls nie ouers se ontevredenheid met die openbare skool kan of sal besweer nie. Van Galen (1988(a):106) waarsku dienaangaande tereg "... it is probable that prohibition or unreasonable restrictions of home education will further alienate already disenchanted parents".

Ter wille van 'n beter perspektief moet egter in gedagte gehou word dat huisskole reeds kragtens wet in alle of die meeste state in die VSA erken word en dat daar'n goeie gesindheid in sommige state tussen huisskole en onderwysowerhede en -personeel bestaan. Op grond daarvan kan verwag word dat die huisskool in die toekoms nog meer inslag sal vind. Trouens, as die klem wat in die huidige tydsgewrig gelê word op die regte van die individu en op die daarmee gepaardgaande vryheid van assosiasie (vgl. Jonathan, 1989:321) ook in die onderwys tot sy logiese konsekwensies deurgevoer word, is daar weinig of geen morele regverdiging waarom leerlinge verplig moet word om openbare of privaatskole by te woon nie, of waarom ouers in enige gemeenskap nie die reg mag uitoefen om 'n kind in 'n huisskool eerder as in 'n openbare skool te plaas nie. Dié standpunt word gesteun deur uitsprake van die Amerikaanse hooggeregshof wat nie net die primêre rol van die ouer in sy kind se opvoeding bevestig nie, maar dit ook duidelik stel dat die beginsel van vryheid "... excludes any general power of the state to standardize its children by forcing them to accept instruction from public teachers only" (Cizek, 1990:112).

Daarmee word nie ontken dat 'n staat inderdaad verantwoordelikheid moet aanvaar vir die voorsiening van onderwys ten einde te verseker dat daar te alle tye genoeg goedopgeleide burgers is om aan ' $n$ land se mannekragbehoeftes te voldoen nie. As sodanig lê die staat se belang egter grootliks in die resultate van die onderwys en nie soseer in die wyse waarop kinders onderrig word nie. Pitman (1987:284) wys tereg daarop dat ' $n$ maatreël waardeur skoolbywoning verplig word wel in 'n groot mate daarin kan slaag om kinders 'n skool te laat bywoon, maar geensins kan verseker dat kinders behoorlik en effektief onderrig word nie. In die lig van die staat se belang by die onderwys, kan geredeneer word dat skoolpligtigheid nie noodwendig hoef te beteken dat kinders op 'n spesifieke plek en/of wyse onderrig moet word nie, maar bloot dat hulle onderwys van 'n aanvaarbare standaard moet kry. 
Hoewel die akademiese standaard van huisskole oor die algemeen gunstig vergelyk met dié van openbare skole behoort van staatsweë maatreëls getref te word wat sal verseker dat minstens dieselfde standaard as in openbare skole gehandhaaf word. Daar kan byvoorbeeld gedink word aan 'n kernleerplan wat gevolg moet word en gereelde toetsing. Dit sou ook as vereiste gestel kon word dat die ouer wat 'n huisskool bedryf, oor tersiêre opleiding en/of 'n onderwysdiploma moet beskik, hoewel Cizek (1990:116) daarop wys dat die meeste state in die VSA egter nie op hierdie stadium 'n onderwysdiploma vereis nie.

Gedagtig aan die akademiese prestasie van kinders in huisskole en die behoefte aan behoorlik opgeleide mannekrag, skyn dit des te meer noodsaaklik te wees dat huisskole maksimale steun behoort te geniet. In die lig daarvan word die verwagting gekoester dat die goeie gesindheid jeens huisskole in sommige state in die VSA ook sal lei tot beter begrip en noue(r) samewerking tussen huisskole en konvensionele skole. Die mate waarin huisskole deur die publiek en die owerhede aanvaar word, skyn 'n bepalende faktor te wees vir die samewerking en ondersteuning waarop gereken kan word. In dié verband word aangevoer dat owerhede nie nodig het om huisskole as 'n bedreiging te sien nie. Die rede daarvoor is klaarblyklik dat huisskole nie tot die massa spreek nie, soos Wright (1988:112) ook te kenne gee as hy beweer "... it is unlikely that home schooling will become a major alternative education program in our society...". Daarvan getuig die geringe persentasie leerlinge wat hulle tans in huisskole bevind immers ook.

Onderwysowerhede en onderwysers kan op verskillende maniere hulp en leiding aan huisskoolouers verskaf om hulle beter toe te rus vir hul taak. Terselfdertyd kan dit ook betrekkinge tussen huisskole en openbare en privaatskole bevorder. In dié verband bestaan daar onder andere die volgende moontlikhede: biblioteekgeriewe en ander mediatoerusting sowel as lesmateriaal kan tot die beskikking van huisskole geste! word; huisskoolkinders kan inskakel by die buitemuurse aktiwiteite (soos kultuur en sport) van openbare en privaatskole; huisskoolkinders kan toegelaat word om konvensionele skole by te woon net vir die onderrig van bepaalde vakke (vgl. Cox, 1990:9; Frost \& Morris, 1988:227; Cizek, 1990:120; Knowles, 1989:404). Nog 'n wyse waarop huisskole ondersteun kan word, is deur die instelling van afstandsonderrigsentra. Sulke sentra sou nie net studiemateriaal kan verskaf aan ouers wat daaraan behoefte het nie, maar sou ook as eksaminerende liggaam kon optree. Daarbenewens sou dit ook die voordeel kon inhou dat kinders wat by so 'n sentrum geregistreer is, onthef kon word van die verpligting om 'n openbare of privaatskool by te woon.

Wat nie in die debat oor huisskole uit die oog verloor mag word nie, is dat huisskole waarskynlik in 'n bepaalde behoefte kan voorsien waaroor by sommige ouers bedenkinge bestaan of die openbare skool werklik daaraan kan voldoen. Knowles 
(1988(b):82) stel dit duidelik:

To mcet the necds of different children it is appropriate 10 consider varieties of education models, of which home schooling is one alternative.

In die lig hiervan wil dit voorkom of huisskole "... a true trend of the future" (Frost \& Morris, 1988:223) is en as alternatiewe vorm van onderwys spesifiek met die oog op die RSA ondersoek behoort te word.

\section{BIBLIOGRAFIE}

BOULTER, H. 1990. The World Education Service: Cases Reviewed. Education Now, 2(8):21-23.

CAMPBELL, R.F. 1976. Public Schools and the Challenge of Cultural Pluralism. Theory into Practice, 15(4):260-266.

CHARvoZ, A. 1988. Reactions to the Home School Research. Dialogues with Practitioners. Education and Unan Society, 21(1):85-95.

CIZEK, GJ. 1990. Home Education Altcrnatives vs. Accountability. Educational Policy, 4(2):109-125.

COMMON, R.W. \& MACMULLEN, M. 1986. Home Schooling ... a Growing Movement. Education Canada, 26:4-7.

COX, B. 1990. Making Home-Based Education a Normal and Available Option for all. Education Now, 2(8):8-9.

DE VILLIERS, E.P. 1992. Persoonlike onderhoud met mev. De Villiers (stigterslid van die Vereniging vir Gereformcerde Tuisskole) op 24 Januarie 1992

DIVOKY, D. 1983. The New Pioneers of the Home-Schooling Movement. Phi Della Kappan, 64(6):395399.

FROST, E.A. \& MORRIS, R.C. 1988. Docs Home-Schooling Work? Somc Insights for Academic Success. Contemporary Education, 59(4):223-227.

HUNTEMANN, G.H. 1964. Seksualitcit in het modernc leven en wat de Bijbel crvan zegt. Wageningen : Zomer en Keunings.

JONATHAN, R. 1989. Choice and Control in Education: Parental Rights, Individual Liberties and Social Justicc. British Joumal of Educational Studies, 37(4):321-338.

KNOWLES, J.(;. 1988(a). Introduction. The Context of Home Schooling in the United States. Education and Uman Sociery, 21(1):5-15.

KNOWLES, J.G. 1988(b). Parents' Rationales and Teaching Methods for Home Schooling. The Role of Biography. Education and Uman Society, 21(1):69-84.

KNOWLES, J.G. 1989. Cooperating with Home School Parents. A New Agenda for Public Schools? Utban Education, 23(4):392-411.

LOUGHREY, M.E. \& Harris, M.B. 1990. A Descriptive Study of at Risk High School Students. The High School Joumal, 73(4):187-193.

LOUW, G.J.J. 1991. Die sogenaamde moderne opvalting van seksualiteit en die implikasies daarvan vir die opvocding. Koers, $56(3): 447-461$.

LOWDEN, S. 1990. 600 Teachers Encourage Learning Outside The School System! Education Now, $2(8): 4.5$.

MACKLIN, E.D. 1988. AIDS: Implications for Families. Family Relations, 37(2):141-148.

MAYBERRY, M. 1988. Characteristics and Attitudes of Families who Home School. Education and Urban Society, 21(1):32-41.

MAYBERRY, M. 1989. Home-Based Education in the United States: Demographics, Motivations and Educational Implications. Educational Review, 41(2):171-180.

Koers $57(3)$ 1992:355-372 
MEIGHAN, R. 1984. Political Consciousness and Home-Based Education. Educational Review, 36(2):165-173.

MEIGHAN, R. 1990. Schooling Can Seriously Damage your Education? Education Now, 2(8):2-3.

MULKOVA, ZA. 1989. The Ouality of Mass Education. Prospects, 19(1):33-45.

ORNSTEIN, A.C. 1990. The Growing Popularily of Private Schools. The Clearing House, 63(5):210-213

PITMAN, M.A. 1987. Compulsory Education and Home Schooling. Truancy or Prophecy? Education and Uban Society, 19(3):280-289.

RAKESTRAW, J.F. \& Rakestraw, D.A. 1990. Home Schooling: A Question of Quality, an Issue of Rights. The Educational Forum, 55(1):67-77.

RAY, B.D. 1988. Home Schools. A Synthesis of Research on Characteristics and Learner Outcomes. Education and Urban Society, 21(1):16-31.

RUPIK, P. 1990. Putting Together a Home-Based Education Package. Education Now, 2(8):6-7.

SKIERA, E. 1990. The Progressive Education Movement and School in Europe - Developments, Teaching-Mcthod Profiles, Perspectives. Education, 41:7-28.

STEINBACHER, J, 1971. The Child Seducers. Educator Publications.

VAN GALEN, J.A. 1988(a). Becoming Home Schoolers. Urban Education, 23(1):89-106.

VAN GALEN, JA. 1988(b). Ideology, Curriculum and Pcdagogy in Home Education. Education and Urban Society, 21(1):52-68.

WARTES, J. 1988. The Washingt on Home School Project. Quantitative Measures for Informing Policy Decisions. Education and Uran Society, 21(1):42-51.

WEBB, J. 1989. The Outcomes of Home-Based Education: Employment and Other Issues. Educational Review, 41(2):121-133.

WEBB, J. 1990. Children Learning at Home: Findings from Case Studies. Education Now, (2)8:10-11.

WRIGHT, C. 1988. Home School Research. Critique and Suggestions for the Future. Education and Ußan Society, 21(1):96-113.

ZEICHNER, K.M. 1991. Contradictions and Tensions in the Professionalization of Teaching and the Democratization of Schools. Teachers College Record, 92(3):363-379. 